\title{
Mobilization of uranium in the alluvial plains of Punjab, India: release from sediment to groundwater.
} MS. RITU BALA, MSC, KARAN VEER AND DEBABRATA DAS

Panjab University

Presenting Author: RITUBALA95@GMAIL.COM

Alluvial plains of Punjab state are in news because of alarming levels of uranium reported from its groundwater. Source of uranium in the water is a subject of debate from quite long time. Geochemical study of radionuclides in the sub-surface sediments may provide the required information of the concentration and processes governing mobilization of uranium. In the present study, sediment samples were obtained from the central part of south-west Punjab along the soil profile with the help of manual hand auger and were analysed for major and trace element analysis.

Uranium concentration reaches up to $10 \mathrm{ppm}$ in few of sediment samples with a mean of $4 \mathrm{ppm}$. Higher concentration in few of the samples gives indication towards uranium accumulation zones in the sediments Uranium gets released out of the sediments under the prevailing redox conditions. Uranium leaching can be accessed from the sediments with the distribution pattern of thorium and uranium which is largely determined by the oxidation and leaching of uranium during weathering, with the immobile thorium left behind. The value obtained for eTh/eU between 3 to 6 and $\mathrm{eTh} / \mathrm{K}$ between 5 to 10 is consistent with alluvial sediments in oxidising terrestrial environment and thus suggests uranium mobilization through weathering or leaching.

Uranium mineralization has been reported from the tertiary and older sedimentary rocks of Siwaliks by Atomic Minerals Directorate (AMD). Siwaliks contributes to the most of groundwater recharge in the Punjab region. Uranium because of its soluble nature may get transported through oxygenated groundwater and there are chances that these sediments may have adsorbed $U$ from the groundwater that used to flow through paleochannels under anaerobic conditions. Although this study does not confirms the hypothesis that uranium is transported from the Siwalik sediments along with groundwater but it confirms that soil of the region has high concentration of uranium from where uranium is leaching into the aquifer, contaminating the water sources. 